See discussions, stats, and author profiles for this publication at: https://www.researchgate.net/publication/328590011

\title{
Taking it from the team: Assessments of bias and credibility in team-operated sports media
}

Article in Newspaper Research Journal · October 2018

DOI: $10.1177 / 0739532918806890$

CITATIONS

0

3 authors, including:

Michael W. Wagner

University of Wisconsin-Madison

43 PUBLICATIONS 279 CITATIONS

SEE PROFILE
READS

23

Some of the authors of this publication are also working on these related projects:

Who Gets Covered? Ideological Extremity and News Coverage of Members of the U.S. Congress, 1993 to 2013 View project

Political Communication Forum View project 


\title{
Taking it from the team
}

Assessments of bias and

Newspaper Research Journal

(C) 2018 NOND of AEJMC

Article reuse guidelines: sagepub.com/journals-permissions DOI: $10.1177 / 0739532918806890$ journals.sagepub.com/home/nrj

@SAGE

\section{credibility in team-operated sports media}

\author{
By Michael Mirer, Megan A. Duncan and Michael W. Wagner
}

\begin{abstract}
Team- and league-operated media play a growing role in the sports media system. Few have looked at how audiences perceive the credibility of in-house content, which regularly mimics traditional sports journalism. An experimental analysis finds that even among fans, independent media content is rated more credible than that produced in-house. Fans view stories accusing their team of wrongdoing as biased even as they find them credible.
\end{abstract}

\section{Keywords}

brand content, journalism, media bias, sports journalism, hostile media perception, news credibility, sports fandom

\footnotetext{
A fter months of frenzied news coverage, accusations of wrongdoing and punishments, a federal judge overturned an National Football League (NFL)-imposed four-game suspension for New England Patriots quarterback Tom Brady on
}

Mirer is visiting assistant professor, Department of Journalism, Advertising and Media Studies, University of Wisconsin-Milwaukee.

Duncan is assistant professor, Department of Communication, Virginia Tech University. Wagner is associate professor, School of Journalism and Mass Communication, and is affiliated with the Department of Political Science and La Follette School of Public Affairs, University of Wisconsin-Madison. Wagner is the corresponding author: michael.wagner@wisc.edu. 
September 3, 2015, seemingly ending the legal proceedings in the scandal that came to be known as "Deflategate." One story's "lede" highlighted Brady's victory, noting, "Tom Brady beat the NFL in the 'Deflategate' and the judge nullified the league's 4-game suspension of Brady." Another story took a different angle, couching the judge's decision within the context of the seriousness of the charges against the Patriots star, writing, "A federal judge erased New England Patriots quarterback Tom Brady's four-game suspension Thursday for the Deflategate controversy that the NFL claimed threatened football's integrity."

The first story was 200 words. It quoted only from the judge's decision and stressed that "No. 12 will be under center for New England." The second story eclipsed 700 words. It highlighted the judge's decision, but also noted how Brady was accused of a conspiracy to use under-inflated footballs in a playoff game, that the NFL was appealing the decision, and that the Patriots received other punishments for under-inflating footballs.

While both stories were accurate and written in traditional news formats, the second story was written by a journalist for ESPN.com, the leading sports news website in the world. The first story appeared on Patriots.com, the official site of the New England Patriots. It was written by a team employee, albeit one that the website claimed operated "independently" from the team that signed his paychecks. ${ }^{1}$ Similar to professional "brand content journalism" publications of companies GE, Microsoft, Tesla and Intel, these providers produce content forms that mirror traditional journalistic forms even though they are not independent, self-publishing their content and distributing it to consumers. ${ }^{2}$

Digital media enabled a proliferation of new outlets for news and opinion content, challenging legacy news media's considerable advantage over information control. ${ }^{3}$ In sports media, a range of new voices have found significant platforms alongside legacy news media outlets. Digital tools gave teams and leagues the ability to start their own news divisions, which compete with traditional outlets. ${ }^{4}$ As they have become content producers, sports teams have borrowed the genre conventions - if not the ethical norms - of journalism in hopes being accepted as credible news sources instead of being treated as public relations. ${ }^{5}$

Teams and leagues borrow heavily from journalism, hiring former sports reporters to produce this content. Their hires stress journalistic identity, ${ }^{6}$ producing material that looks similar to what is found at independent outlets. Some, such as Patriots.com or mlb.com, even carry disclaimers noting that the reporters are not being edited by team personnel. Information published on these sites targets a highly partisan audience, fans. The assertion of independence by these outlets speaks to a common understanding that fans expect something more than the team's voice if they are to view a website as credible and worth their time.

This study examines whether audiences trust team media reporting differently than traditional news media reporting. The study uses a $2 \times 3$ experiment to examine how sports partisans process news. The authors do so by manipulating the publisher of the news (traditional news, hometown team website, rival team website) and the role of the story (accusing a rival team of wrongdoing, being accused by the rival). This study also advances theory by revealing a novel interaction between news source and news content. 


\section{Literature Review}

The relationship between sports and mass media extends back more than two centuries. ${ }^{7}$ The news produced often served a promotional function for sporting institutions and media entities; sports events encouraged consumption of media, which made sporting events more popular. Leagues and teams worked to attract media coverage they could not provide. ${ }^{8}$ Even when teams and leagues did develop their own media production arms, they often relied on media partners for mass distribution. ${ }^{9}$

\section{The Emergence of Branded Sports News Websites}

Since teams began using their websites as news portals around $2000,{ }^{10}$ two models have emerged: one team-based and one more centralized and independent. The Cincinnati Bengals pioneered the team-based model by hiring Geoff Hobson, the Bengals reporter for the city's newspaper, in 2000 into a role he still occupies. Within the NFL, National Basketball League (NBA), National Hockey League (NHL) and major college athletics, writers work directly for the team or university. The amount of autonomy varies. In 2016, the vast majority of professional teams listed online content producers in their media guides. ${ }^{11}$

The year after the Bengals hired Hobson, Major League Baseball (MLB) Advanced Media, the company that operates the websites for each of MLB's 30 teams, started hiring beat writers to produce news for team websites. Those writers work for MLB's subsidiary, but their work appears on team websites alongside links where fans can buy tickets and merchandise.

The reasons for hiring content producers vary across organizations. Some hired writers in response to diminishing newspaper coverage. ${ }^{12}$ Team sites have created sponsored content, allowing them to deepen ties with sponsors. ${ }^{13}$ Entities also use in-house media to shape the sports media agenda and influence the ways stories are covered. ${ }^{14}$

Writers who have gone to team sites still view themselves as engaged in journalism, even if they no longer are fully independent. ${ }^{15}$ The work they produce often mimics traditional sports journalism, whose conventions are deployed to communicate credibility. ${ }^{16}$ At the same time, sports reporters have never had the same expectations of objectivity as news reporters ${ }^{17}$ :

If a Chicago newspaper provided a visiting basketball team coverage as sympathetic as it provides the hometown Chicago Bulls, this would be understood as treachery, as if The Times of London had treated press releases from Hitler's Germany with the same deference as those from 10 Downing Street. ${ }^{18}$

\section{Audience Perceptions of Credibility}

Journalistic behavior is only one side of the credibility question, one with a long history in journalism studies. This study focuses on audience perception of credibility, where scholars focus on individuals' perceptions of media organizations, the motivations of reporters and the perceptual lenses audiences use when evaluating news content. ${ }^{19}$ As news transitions from print to online presentation, readers remain consistent in how they evaluate news credibility. ${ }^{20}$ Branded content has blurred the line between 
independently produced news and commercial media. ${ }^{21}$ Readers notice the difference and rate independent media as more credible. ${ }^{22}$ Although writers claim independence, because team websites bear the name and other cues that designate the content as sponsored by a team, news audiences should be more likely to rate stories published by teams as less credible than stories by independent media.

\section{H1:}

Stories published by an independent news source will be rated more credible than the news stories published by team-owned news sources.

\section{Fandom as Identity}

Social identity theory predicts that group affiliation is the primary lens through which individuals filter new information and situations. ${ }^{23}$ Once entrenched, identity becomes a powerful heuristic. Partisans use their group identification to make judgments when faced with controversies. ${ }^{24}$

Team identification affects processing of sports news. ${ }^{25}$ Identification with teams has been conceptualized as occurring along a continuum, with high-identification fans feeling greater attachment to their teams. ${ }^{26} \mathrm{Fan}$ identity is stable, and fans harshly view disloyalty among those who claim to support the team. ${ }^{27}$

\section{Identity and Hostile Media Effect}

This partisan nature of sports fandom fits squarely within the context of the hostile media effect, a phenomenon described as inclination of partisan observers to view news media content as biased against their side. ${ }^{28}$ Turner found that this effect is often based solely on the source of the information, even when the content is held constant. ${ }^{29}$ Arpan and Raney found evidence of the hostile media effect among sports audiences, although the degree of hostility varied based on the source. ${ }^{30}$

\section{Content and Source Effects}

Some studies have manipulated the content of the news story or the publication to measure effects. ${ }^{31}$ Others have targeted groups who were expected to be partisans on an issue..$^{32}$ While these experiments advanced scholars' understanding of how partisans process information based on its publication or its content, it leaves unanswered what happens when the two collide.

Studies that manipulated the publication have used name brands with a reputation for bias and kept the content constant have found that partisans rated the stories published in a counter-attitudinal space as more biased than pro-attitudinal publications..$^{33}$ Because these manipulations included clips from authentic news programming, they conflate the publication's reputation for bias with actual content bias.

The authors addressed these limitations here by isolating the publication brand from the content to ensure that a simple name change does indeed affect perception of bias and further to test the perception of bias from both fans and rivals. The prediction is that manipulating the source will affect bias perception. 


\section{H2:}

Fans of a team will rate news stories published by the team they favor as less biased than those who view the team as their rival.

Recent research created two versions of stimulus content to examine interactions between the participant's beliefs and the content of the news story. Reid manipulated the political party of a source criticizing a political movie, finding that readers found less bias when the attack came from within their own party. ${ }^{34}$

This study takes advantage of a population divided by fan allegiance to a particular NFL team to allow for random assignment to a content condition. Thus, the authors test the perceptions of bias between a local team and its rival's website while also measuring the effect of the pro-attitudinal and counter-attitudinal message attributes. The prediction is that fans will rate a story as more biased when their preferred team is criticized than when their team criticizes a rival. Conversely, people who see a team as their rival should rate a story as more biased when the rival attacks another team than when the rival team is attacked by another team.

\section{H3a:}

Fans of a team will rate a story as more biased when the team is accused of wrongdoing than when it is doing the accusing.

\section{H3b:}

Fans who see a team as their rival will rate a story when that team is accusing another of wrongdoing as more biased than when the team is accused of wrongdoing.

Because studies have found evidence of the hostile media effect in the cases of counter-attitudinal publications and in the cases where the content of the study manipulates the ideology of the attacker, this study investigates the strength of the effect of publisher-whether a story is covered by "team media" or traditional news mediacompared with the content and checks for an interaction.

\section{RQ1:}

Which activates reception: the team's role as accuser or accused or the source of the news?

\section{Method}

To investigate how the publisher of a sports article affects the evaluations of bias and credibility of that story, the authors use an experimental design that manipulated source cues in a fabricated news story about an investigation into a rules violation. Two versions of the story were used to test for how the role a team played in the story resulted in different hostile media effects. A group of 308 students at a large Midwestern university completed this experiment embedded in an online survey. 
Participants were recruited by email from university courses to participate in the experiment. First, participants answered questions about their interest in different sports. Participants chose from a list of all NFL teams the team they were most a fan of and the team they considered their biggest rival. Just over half of the participants (51 percent) reported they were fans of the Green Bay Packers, while another 22 percent said the Packers were their team's biggest rival. After answering these pretest questions, participants were randomly assigned to one of six conditions in this 3 (Packers media platform, Minnesota Vikings's media platform, traditional media) by 2 (team accused/ accuser) design. After reading a news story that acted as the stimulus material, participants answered questions about their perceptions of credibility and bias.

Two versions of a sports news story were placed on digital images to make it appear as if the story was published from either USA Today, packers.com or vikings.com (a rival of the Packers). To minimize the design differences between the two team websites, the same peripheral cues (advertisements, announcements) were used in both templates. The USA Today story had no peripheral cues, reflecting the actual website design.

The 275-word news story given to participants describes an accusation by one team that a rival team has violated NFL anti-tampering policy by expressing desire to acquire a particular player while that player was under contract to the first team. The NFL usually punishes teams for this with fines or by taking away draft picks. The events described in the story are loosely based on real-life violations - though none concerned the teams chosen for this experiment. In the first version of the fabricated text, the Packers accused the Vikings of tampering. In the second version, the roles of the teams are reversed. While the names of the players and general managers were changed to reflect the real names of the respective teams, the remainder of the text was the same in both versions. Care was taken to give equal space to each team, following traditional journalistic standards of objectivity and credibility.

\section{Variables}

To measure perceptions of news credibility, participants were asked to indicate how well the story met their expectations, 1 (low) to 5 (high), along seven dimensions: trustworthiness, credibility, believability, truthfulness, fairness, accuracy and objectivity. ${ }^{36}$ The answers to those questions were averaged to create a credibility index score $(M=2.78, S D=0.39)$. The Cronbach's alpha for the index (.853) indicates high internal reliability.

\section{Packers bias, Vikings bias and net team bias}

During the posttest, participants were asked how biased they thought the news story they read was biased regarding the Packers. The answers ranged from -2 (very biased against) to 2 (very biased in favor), where 0 was neutral $(M=0.11, S D=0.79$ ). Participants were asked how biased they thought the news story they read was biased regarding the Vikings. The answers ranged from -2 (very biased against) to 2 (very biased in favor), where 0 was neutral $(M=-0.09, S D=0.4)$. The bias toward the Packers and the inverse of bias toward the Vikings were added to create a net team bias score from -4 (biased against the Vikings and in favor of the Packers) to 4 (strongly biased in favor of the Vikings and against the Packers $)(M=0.24, S D=1.41)$. The answers to the two items were negatively correlated, $r(263)=-.75, p<.001$. 


\section{Manipulation Check}

After answering the dependent variable questions, participants were asked the source of the news story they were shown. Seventy-three percent of the respondents answered correctly. The most common incorrect answer was the NFL Network, which likely reflects a misunderstanding of the ownership structure of team websites.

\section{Results}

To test H1, which posited stories published by an independent news source would be rated as more credible than the news stories published by team-owned sources, the credibility index was compared across sources in an independent-sample $t$ test. Participants rated the USA Today stories $(N=98)$ as significantly more credible $(M=$ $2.85, S D=0.36)$ than stories published on the team-owned sites $(N=210)(M=2.72$, $S D=0.43), t(217)=2.93, p=.004$.

To test H2, which predicted that fans who see a news story published by the Packers's website would rate that story as less biased than fans who view the Packers as a rival to their team, an independent-sample $t$ test was used. This test was only among those who were assigned to the Packers website conditions $(N=75)$. There was no significant difference in the bias rating between those who identified themselves as the Packers's fans $(M=0.14, S D=1.44)$ and those who identified the Packers as their team's chief rival $(M=0.58, S D=1.74), t(38.39)=1.09, p=.282$. This finding does not support a difference in bias evaluations between fans and rivals when only the source of the story changes. For those who did not identify themselves as a fan of either team, a multivariate analysis of variance (MANOVA) found non-significant effects on source credibility, $F(2)=1.724, p=.185$, observed power $=.352$, or perceptions of bias toward either team, $F(2)=1.282, p=.283$, observed power $=.271$.

Table 1 reports the means of the perceived bias of the news story depending on the team that filed the complaint among those who are fans of the Packers, those who saw the Packers as rivals and those who do not fall into either of those categories. These means were used to test $\mathbf{H 3} \mathbf{a}$ and $\mathbf{H 3} \mathbf{b}$, which focused on how the fandom of the audience influenced the perceived bias in the news story.

To test H3a, which posited that fans of a team will rate a story as more biased when the team they root for is accused of wrongdoing than when it has been wronged, a oneway analysis of variance (ANOVA) was performed only on data from the group who identified themselves as fans of the Packers $(N=159)$. This test compared the team role condition with both Packers bias and Vikings bias. Regarding Packers bias, the test revealed a significant difference between those who were assigned to conditions where the Packers accused the Vikings of wrongdoing $(M=0.27, S D=0.69)$ and those who were assigned to conditions where the Vikings accused the Packers of wrongdoing $(M=-0.24, S D=0.75), F(1,157)=19.90, p<.001$.

Supporting H3a, a significant difference was found between those were assigned to read a story in which the Packers accused the Vikings $(M=-0.27, S D=0.66)$ and those who read that the Vikings accused the Packers $(M=0.28, S D=0.68), F(1$, $153)=26.31, p<.001$.

H3b posited that fans who see the Packers as their rival will rate a story as more biased when that team is accusing another of wrongdoing than when the Packers are 


\begin{tabular}{|c|c|c|c|c|}
\hline \multicolumn{5}{|c|}{$\begin{array}{l}\text { Perceived Bias Regarding the Role of the Team in the Content of the Story } \\
\text { Separated by Participant Partisan Status }\end{array}$} \\
\hline & Complaint & $N$ & Mean & $S D$ \\
\hline \multicolumn{5}{|l|}{ Non-partisans } \\
\hline \multirow[t]{2}{*}{ Bias regarding Packers } & Packers filed & 45 & 0.35 & 0.67 \\
\hline & Vikings filed & 41 & 0.02 & 0.85 \\
\hline \multirow[t]{2}{*}{ Bias regarding Vikings } & Packers filed & 44 & 0.20 & 0.70 \\
\hline & Vikings filed & 41 & 0.02 & 0.79 \\
\hline \multicolumn{5}{|l|}{ Packers rivals } \\
\hline \multirow[t]{2}{*}{ Bias regarding Packers } & Packers filed & 39 & 0.48 & 0.75 \\
\hline & Vikings filed & 32 & -0.15 & 0.88 \\
\hline \multirow[t]{2}{*}{ Bias regarding Vikings } & Packers filed & 38 & 0.5 & 0.60 \\
\hline & Vikings filed & 31 & -0.12 & 0.76 \\
\hline \multicolumn{5}{|l|}{ Packers fans } \\
\hline \multirow[t]{2}{*}{ Bias regarding Packers } & Packers filed & 85 & 0.27 & 0.69 \\
\hline & Vikings filed & 74 & -0.24 & 0.75 \\
\hline \multirow[t]{2}{*}{ Bias regarding Vikings } & Packers filed & 85 & 0.27 & 0.66 \\
\hline & Vikings filed & 70 & -0.28 & 0.68 \\
\hline
\end{tabular}

accused of wrongdoing. For this test, the authors limited the analysis to the group who viewed the Packers as their team's biggest rival $(N=71)$. Regarding bias toward the Packers, the test revealed a significant difference between those who were assigned to conditions where the Packers accused the Vikings of wrongdoing $(M=0.49, S D=$ $0.76)$ and those who were assigned to conditions where the Vikings accused the Packers of wrongdoing $(M=-0.16, S D=0.88), F(1,69)=10.93, p=.002$. Regarding bias toward the Vikings, the test revealed a significant difference between those were assigned to read a story where the Packers accused the Vikings $(M=$ $-0.50, S D=0.60)$ and those who read that the Vikings accused the Packers $(M=$ $0.13, S D=0.76), F(1,67)=14.61, p<.001$. While there was a significant difference between the bias based on who was being accused of wrongdoing, these results are unexpected because the directionality of the bias toward both teams is the same among the group who sees themselves as rivals to the Packers as those who see themselves as fans of the Packers.

To investigate the research question asking if source or content cues were a better predictor of hostile media effect, a MANOVA was performed. The means listed under perceived bias in Table 2 indicate that participants saw the story in which the Packers filed the complaint as biased in favor of the Packers $(M=0.35, S E=0.058)$ and biased against the Vikings $(M=-0.31, S E=0.054)$. Meanwhile, participants who saw the story in which the Vikings filed the complaint viewed it as biased against the 


\section{Table 2}

Role of News Source on Perceived Credibility and Bias

\begin{tabular}{|c|c|c|c|c|c|c|c|c|}
\hline News Source & $\begin{array}{c}\text { Team } \\
\text { that Filed } \\
\text { Complaint }\end{array}$ & $N$ & $\begin{array}{c}\text { Bias } \\
\text { Regarding } \\
\text { Packers }\end{array}$ & $S D$ & $\begin{array}{c}\text { Bias } \\
\text { Regarding } \\
\text { Vikings }\end{array}$ & $S D$ & Credibility & $S D$ \\
\hline \multirow[t]{3}{*}{ USA Today } & Packers & 52 & 0.26 & 0.59 & 0.28 & 0.60 & 2.89 & 0.27 \\
\hline & Vikings & 44 & -0.04 & 0.80 & 0.06 & 0.72 & 2.84 & 0.43 \\
\hline & Total & 96 & 0.12 & 0.71 & 0.18 & 0.66 & 2.87 & 0.35 \\
\hline \multirow[t]{3}{*}{ Packers } & Packers & 52 & 0.63 & 0.65 & 0.46 & 0.60 & 2.81 & 0.34 \\
\hline & Vikings & 45 & -0.15 & 0.90 & -0.28 & 0.69 & 2.73 & 0.39 \\
\hline & Total & 97 & 0.26 & 0.87 & 0.11 & 0.74 & 2.78 & 0.36 \\
\hline \multirow[t]{3}{*}{ Vikings } & Packers & 59 & 0.16 & 0.74 & 0.16 & 0.74 & 2.77 & 0.38 \\
\hline & Vikings & 46 & -0.15 & 0.75 & -0.26 & 0.77 & 2.68 & 0.44 \\
\hline & Total & 105 & 0.02 & 0.76 & -0.01 & 0.78 & 2.73 & 0.41 \\
\hline \multirow[t]{3}{*}{ Total } & Packers & 163 & 0.35 & 0.69 & 0.31 & 0.66 & 2.82 & 0.34 \\
\hline & Vikings & 135 & -0.12 & 0.82 & -0.16 & 0.74 & 2.75 & 0.42 \\
\hline & Total & 298 & 0.13 & 0.79 & 0.09 & 0.73 & 2.79 & 0.3 \\
\hline
\end{tabular}

Note. Perceived credibility was measured on a scale of 1 to 5, where 5 indicated high credibility. Perceived bias regarding by the role of the team in the content of the story was separated by participant partisan status. Bias was measured from -2 to 2 , where 0 was neutral. Negative means indicate perceived bias against the team. These scores do not consider the team partisanship of the individual audience member.

Packers $(M=-0.12, S E=0.063)$ and in favor of the Vikings $(M=0.16, S E=0.059)$. (See the "Total" section at the bottom of the table.)

The statistical results of the MANOVA are listed in Table 3. Results show the test yielded a significant main effect for the role of the team that filed the complaint on bias toward both teams: the Packers $F(1,295)=30.20, p<.001$, and the Vikings $F(1$, $295)=33.16, p<.001$. There was no significant main effect of story source on bias toward the Packers, $F(2,301)=2.5, p=.084$, or the Vikings, $F(2,301)=2.6, p=$ .075 . However, a significant interaction was found between source and team role on bias regarding the Packers, $F(2,301)=3.272, p=0.039$, and regarding the Vikings $F(2,301)=3.46, p=.033$. These results indicate the role of the team in the scenario had a greater effect on perceptions of team bias in the website conditions than in the USA Today source condition.

\section{Discussion}

The rise of digital media has undeniably challenged the authority of legacy journalism, eroding trust in traditional outlets and enabling a group of amateurs and partisans to exert greater influence. The rise of public relations brand content reflects efforts by more institutional actors to take advantage of these same tools to go around journalists and directly reach audiences. Professional football teams are one particularly welldeveloped example of this. The concern - to borrow a phrase from a movie about a 


\section{Table 3}

MANOVA Testing the Effects of Experimental Manipulations on the Perception of
Credibility, Bias Regarding the Packers and Bias Regarding the Vikings

\begin{tabular}{lcccccc} 
& \multicolumn{2}{c}{ Bias_Packers } & \multicolumn{2}{c}{ Bias_Vikings } & \multicolumn{2}{c}{ Credibility index } \\
& $F$ & $\eta_{\mathrm{p}}^{2}$ & $F$ & $\eta_{\mathrm{p}}^{2}$ & $F$ & $\eta_{\mathrm{p}}^{2}$ \\
Corrected model & $8.35^{* * *}$ & .124 & $9.01^{* * *}$ & .132 & 2.19 & .036 \\
News source & 2.50 & .017 & 2.62 & .017 & $3.82^{*}$ & .025 \\
Team role & $30.20^{* * *}$ & .093 & $33.16^{* * *}$ & .101 & 3.25 & .011 \\
Source $\times$ Role & $3.27^{*}$ & .022 & $3.46^{*}$ & .023 & .040 & .000 \\
Error, Total & \multicolumn{2}{c}{295,301} & \multicolumn{2}{c}{295,301} & 295,301
\end{tabular}

Note. MANOVA = multivariate analysis of variance.

$* p<.05 ; * * p<.01 ; * * * p<.001$

different sport-is if sports teams (or politicians or brands) simply build these channels, the audiences will come. We show here that audiences still appear to find value in journalism's semiotics and ideas such as independence. This is true even when audience members have some allegiance to the source of information. Yet it is likely that credibility judgments will continue to evolve and interpretation of news directly from the team will as well.

When it comes to the credibility of informational content, the source still matters. ${ }^{35}$ Subjects, even partisans, viewed news produced by a familiar independent media outlet as more credible than that produced by the team. This suggests audiences still view journalistic independence as a meaningful way of evaluating the merits of a story. Stories produced by in-house outlets still have barriers to clear on gaining audience trust. These findings also suggest that the decision by sporting institutions to borrow heavily from journalism is a smart move in that they are seeking to access journalistic credibility.

However, the strong and persistent main effect of the story context was a surprising result, especially in light of Arpan and Raney, who found such strong results for the publication cue. ${ }^{36}$ This finding deserves further investigation to see if these results can be replicated.

The interaction between the source cues and the publication suggest that independent media may temper perceptions of bias. Study participants were randomly assigned to conditions. Consumers of sports news generally choose their sources. Future work should account for effects when individuals choose an in-house site or a traditional source of news.

In this study, the source of the news was USA Today, and the perception of bias between the team role manipulation conditions made the smallest difference. Figure 1 shows that in conditions where the Packers were accused of wrongdoing, the stories were perceived as near neutral when in USA Today. When participants were assigned to the conditions where the story was published to a team site, the perception of bias when the Vikings were accused increased and the perception of bias when the Packers 


\section{Figure 1}

\section{The Rate of Perceived Bias Regarding Sports Teams by Condition}

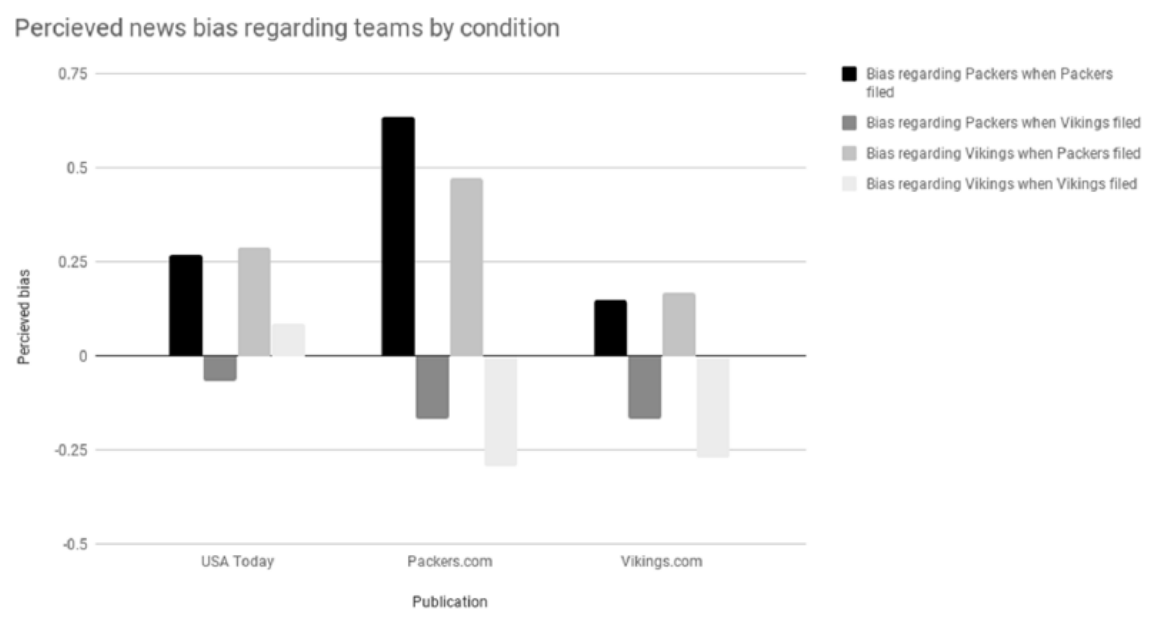

Note. Bias rates greater than zero indicate a perceived bias in favor of the team. Bias rates less than zero indicate a perceived bias against the team.

were accused became apparent. Figure 1 suggests that source matters in the perception of bias, but that its effect may be masked by a very strong effect of story context.

The findings also have implications for the understanding of how sports fandom and media interact. The authors expected an inverse relationship between how fans of different teams viewed stories, but what was found instead were differences of degrees. If the team is at the center of fan identity, the authors expected that information coming directly from the team would carry greater weight. That was not the case. Strength of fandom may help explain how this process works, especially in environments where strong partisans choose their news source. ${ }^{37}$

Finally, cues that lead to credibility judgments appear to be different than the cues that lead to bias judgments. While many hostile media studies focus on the predictors of bias as the single outcome variable, credibility scales include bias and/or suggest that the perception of bias leads to credibility judgments. ${ }^{38}$ It may be that bias measurements are hypersensitive to departures from journalistic norms. Alternatively, perception of bias may be an emotional response, while perception of credibility may be a cognitive process. ${ }^{39}$

\section{Conclusion}

In-house content production is not unique to the world of sports media. Politicians, activist groups and businesses operate their own news production services that produce information that is distributed directly to targeted audiences and published on 
branded channels. ${ }^{40}$ Understanding how audiences view, use and receive this content is crucial if there is to be a comprehensive explanation of media effects in contemporary society.

The research design is not without its limitations. No one source can represent all independent publications. It may be interesting to test the effects of source between specific team websites and the league website (e.g., NFL.com). Regarding external validity, it was anticipated that several participants would be Vikings fans. That was true, but a third team, the Chicago Bears, was more popular, making impossible inferential statistical tests comparing Packers and Vikings fans. Second, the design assigned many Packers fans to read a story published by Vikings.com, something they might not do in the real world. In addition, our measure of fandom did not estimate the degree to which people loved their favorite team. Examining the extremity of fandom may shed additional light on our findings.

The study sample was 70 percent female, whereas women are about 45 percent of the NFL fan base ${ }^{41}$ For at least 10 NFL markets - including the Packers-more than 60 percent of women in those regions identified as sports fans. ${ }^{42}$ The NFL attracts more female fans than any other North American team sport and is actively seeking to attract women as fans - both to sell merchandise and to entice them to enroll their sons in the game despite concerns over the health effects of the sport. ${ }^{43}$

However, the credibility scores for men and women only differed by 0.12 in the sample. What is more, the bias score for coverage of the Packers differed by gender at .04 on the bias scale and the bias score for coverage of the Vikings differed by only 0.01 .

Our study is potentially limited by the fact that college students made up our participant pool. However, as Druckman and Kam demonstrated, there is nothing inherent in using student samples that reduces the realism of the experiment nor do student samples generally differ from non-student samples when seeking to test most questions of civic and political behavior. ${ }^{44}$

These results contain important lessons for journalists and media theorists. For journalists, the authors show that audiences do not believe branded content acts impartially toward topics in which it has an interest. Audiences appear to see this content more as public relations than journalism. Furthermore, it suggests that an assumption of bias is exaggerated when audiences read branded content stories instead of independent news media. For media scholars, these analyses offer insight into the cues audiences use to process the news by introducing evidence that the context of a story may be a stronger hostile media trigger than the source of the news. With further investigation, comparison of cues that produce hostile media effects may lead to an understanding of the mechanisms that cause it.

\section{Editors' Note}

This article was accepted for publication under the editorship of Sandra H. Utt and Elinor Kelley Grusin.

\section{Notes}

1. The Patriots website includes the following disclaimer on stories: "The opinions, analysis and/or speculation expressed on Patriots.com represent those of individual authors, and unless quoted or clearly labeled as such, do not represent the opinions or policies of the New England Patriots organization, front office staff, coaches and executives. Authors' views are formulated independently from any inside knowledge and/or conversations with Patriots officials, including the coaches and scouts, unless otherwise noted." 
2. L. Soza, "Leaders of the Pack: 15 Companies Blazing the Brand Journalism Trail," AirPR, $<$ http:// blog.airpr.com/brand-journalism-trailblazers/> (Aug. 13, 2014).

3. Jane B. Singer, "Who Are These Guys? The Online Challenge to the Notion of Journalistic Professionalism," Journalism 4, no. 2 (2003): 139-163, doi:10.1177/146488490342001.

4. Jason Fry, "Rules of the Game Change as Sports Journalists Compete against Teams They Cover" (St. Petersburg, FL: Poynter Institute, 2011), September 15, http://www.poynter.org/latest-news/topstories/146069/rules-of-the-game-change-as-sports-journalists-compete-against-teams-they-cover/; Molly Yanity, "Publishing for Paydirt: A Case Study of an Athletic Department Writer," International Journal of Sport Communication 6, no. 4 (2013): 478-489.

5. Kate Fitch, "Seeing the 'Unseen Hand': Celebrity, Promotion and Public Relations," Public Relations Inquiry 6, no. 2 (2017): 157-169.

6. Kathleen Bartzen Culver and Michael Mirer, "Constrained Independence: Digital Brand Content in Sports through the Lens of Journalism Ethics," in Ethics for a Digital Age, ed. Bastiaan Vanacker and Don Heider (New York: Peter Lang, 2015), 19-40; Michael Mirer, "Stealing Signs: In-House Sports Reporters and Journalistic Boundary Work" (Doctoral dissertation, University of Wisconsin-Madison, 2016); Tom Hoffarth, "Was the NHL about to Compromise the Integrity of Kings" 'Insider' Hammond?" Los Angeles Daily News, October 11, 2012, http://www.insidesocal.com/tomhoffarth/2012/10/11/ more-on-why-the/.

7. Robert McChesney, "Media Made Sport: A History of Sports Coverage in the United States," in Media, Sport, and Society, ed. Lawrence A. Wenner (Newbury Park: Sage, 1989), 49-70.

8. Bruce J. Evensen, "Jazz Age Journalism's Battle over Professionalism, Circulation, and the Sports Page," Journal of Sport History 20, no. 3 (1993): 229-246, http://library.la84.org/SportsLibrary/JSH/ JSH1993/JSH2003/jsh2003b.pdf; Jonathan Yardley, Ring: A Biography of Ring Lardner (New York: Random House, 1977).

9. John A. Fortunato, The Ultimate Assist: The Relationship and Broadcast Strategies of the NBA and Television Networks (Cresskill: Hampton Press, 2001); Travis Vogan, Keepers of the Flame: NFL Films and the Rise of Sports Media (Urbana: University of Illinois Press, 2014).

10. Chris Jenkins, "League's Web Site Links Teams Internet to Be Just like TV," USA Today, August 9, 2000.

11. Mirer, "Stealing Signs."

12. Richard Perez-Pena, "As Coverage Wanes, Los Angeles Kings Hires Its Own Reporter," The New York Times, September 28, 2009, http://www.nytimes.com/2009/09/28/business/media/28kings.html? r r=0.

13. John A. Fortunato, Sports Sponsorship: Principles and Practices (Jefferson, NC: McFarland, 2013); Jay Scherer and Steven J. Jackson, "Producing Allblacks.com: Cultural Intermediaries and the Policing of Electronic Spaces of Sporting Consumption," Sociology of Sport Journal 25, no. 2 (2008): 187-205.

14. John Koblin, "How Roger Goodell and ESPN Use Each Other," Deadspin, October 1, 2013, http:// deadspin.com/how-roger-goodell-and-espn-use-each-other-1434043423.

15. Culver and Mirer, "Constrained Independence"; Michael Mirer, "'I Did What I Do' Versus 'I Cover Football': Boundary Work, in-House Media and Athlete Protest," Journalism Practice 12, no. 3 (2018): 251-267, doi:10.1080/17512786.2017.1284016; Yanity, "Publishing for Paydirt."

16. S. Elizabeth Bird and Robert W. Dardenne, "Myth, Chronicle and Story," in Social Meanings of News, ed. Dan Berkowitz (Thousand Oaks: Sage, 1997), 333-350.

17. Marie Hardin, "Survey Finds Boosterism, Freebies Remain Problem for Newspaper Sports Departments," Newspaper Research Journal 26, no. 1 (2005): 66-72; David Rowe, "Sports Journalism: Still the 'Toy Department' of the News Media?" Journalism 8, no. 4 (2007): 385-405, doi: $10.1177 / 1464884907078657$.

18. Michael Schudson, "The Objectivity Norm in American Journalism," Journalism 2, no. 2 (2001): 149170, doi:10.1177/146488490100200201.

19. Al Gunther, "Biased Press or Biased Public? Attitudes toward Media Coverage of Social Groups," Public Opinion Quarterly 56, no. 2 (1992): 147-167, http://poq.oxfordjournals.org/content/56/2/147.short.

20. Rasha A. Abdulla, Bruce Garrison, Michael Salwen, Paul Driscoll and Denise Casey, "The Credibility of Newspapers, Television and Online News" (paper presented in the Mass Communication \& Society Division, Association for Education in Journalism \& Mass Communication convention, Miami, FL, August 9, 2002); Andrew J. Flanagin and Miriam J. Metzger, "Perceptions of Internet Information Credibility," Journalism \& Mass Communication Quarterly 77, no. 3 (2000): 515-540.

21. Andy Bull, Brand Journalism (London: Routledge, 2013); Rebecca D. Swenson, "Brand Journalism: A Cultural History of Consumers, Citizens, and Community in Ford Times" (doctoral dissertation, School of Journalism and Mass Communication, University of Minnesota, 2012). 
22. James T. Cole II and Jennifer D. Greer, "Audience Response to Brand Journalism: The Effect of Frame, Source, and Involvement," Journalism \& Mass Communication Quarterly 90, no. 4 (2013): 673-690, doi:1077699013503160; Eva A. van Reijmersdal, Peter C. Neijens and Edith G. Smit, “Customer Magazines: Effects of Commerciality on Readers' Reactions," Journal of Current Issues \& Research in Advertising 32, no. 1 (2010): 59-67.

23. Henri Tajfel, "Social Psychology of Intergroup Relations," Annual Review of Psychology 33, no. 1 (1982): 1-39.

24. Paul Goren, Christopher M. Federico and Miki Caul Kittilson, "Source Cues, Partisan Identities, and Political Value Expression," American Journal of Political Science 53, no. 4 (2009): 805-820, doi:10.1111/j.1540-5907.2009.00402.x.

25. Albert H. Hastorf and Hadley Cantril, "They Saw a Game: A Case Study," Journal of Abnormal Psychology and Social Psychology 49, no. 1 (1954): 129-134, doi:10.1037/h0057880; Daniel L. Wann and Nyla R. Branscombe, "Influence of Identification with a Sports Team on Objective Knowledge and Subjective Beliefs," Journal of Sport Psychology 26, no. 4 (1995): 551-567.

26. Daniel L. Wann and Nyla R. Branscombe, "Sports Fans: Measuring Degree of Identification with the Team,” International Journal of Sport Psychology 24, no. 1 (1993): 1-17.

27. Amir Ben Porat, "Football Fandom: A Bounded Identification," Soccer \& Society 11, no. 3 (2010): 277-290, doi:10.1080/14660971003619594; Daniel L. Wann and Nyla R. Branscombe, "Emotional Responses to the Sports Page," Journal of Sport \& Social Issues 16, no. 1 (1992): 49-64, http://jss .sagepub.com/content/16/1/49.short.

28. Robert P. Vallone, Lee Ross and Mark R. Lepper, "The Hostile Media Phenomenon: Biased Perception and Perceptions of Media Bias in Coverage of the Beirut Massacre," Journal of Personality and Social Psychology 49, no. 3 (1985): 577-585, http://web.ebscohost.com.ezproxy .library.wisc.edu/ehost/pdfviewer/pdfviewer?sid=b1a67249-c50a-4ed5-90af-7d4358d59bde@ sessionmgr $15 \&$ vid $=2 \&$ hid $=24$.

29. Joel Turner, "The Messenger Overwhelming the Message: Ideological Cues and Perceptions of Bias in Television News," Political Behavior 29, no. 4 (2007): 441-464.

30. Laura M. Arpan and Arthur A. Raney, "An Experimental Investigation of News Source and the Hostile Media Effect," Journalism \& Mass Communication Quarterly 80, no. 2 (2003): 265-281, doi:10.1177/107769900308000203.

31. Amarina Ariyanto, Matthew J. Hornsey and Cindy Gallois, "Group Allegiances and Perceptions of Media Bias Taking into Account Both the Perceiver and the Source," Group Processes \& Intergroup Relations 10, no. 2 (2007): 266-279; Matthew A. Baum and Phil Gussin, "In the Eye of the Beholder: How Information Shortcuts Shape Individual Perceptions of Bias in the Media," Quarterly Journal of Political Science 3, no. 1 (2008): 1-31.

32. Roger Giner-Sorolla and Shelly Chaiken, "The Causes of Hostile Media Judgments," Journal of Experimental Social Psychology 30, no. 2 (1994): 165-180; Albert C. Gunther and Janice L. Liebhart, "Broad Reach or Biased Source? Decomposing the Hostile Media Effect," Journal of Communication 56, no. 3 (2006): 449-466; Turner, "The Messenger Overwhelming the Message."

33. Kevin Coe, David Tewksbury, Bradley J. Bond, Kristin L. Drogos, Robert W. Porter, Ashley Yahn and Yuanyuan Zhang, "Hostile News: Partisan Use and Perceptions of Cable News Programming," Journal of Communication 58, no. 2 (2008): 201-219.

34. Scott A. Reid, "A Self-Categorization Explanation for the Hostile Media Effect," Journal of Communication 62, no. 3 (2012): 381-399.

35. Phil Meyer, "Defining and Measuring Credibility of Newspapers: Developing an Index," Journalism Quarterly 65 (1988): 567-574.

36. Arpan and Raney, "An Experimental Investigation of News Source and the Hostile Media Effect."

37. Kevin Arceneaux and Martin Johnson, Changing Minds or Changing Channels? Partisan News in an Age of Choice (Chicago: University of Chicago Press, 2013).

38. Frederick Fico, John D. Richardson and Steven M. Edwards, "Influence of Story Structure on Perceived Story Bias and News Organization Credibility," Mass Communication \& Society 7, no. 3 (2004): 301-318.

39. Laura M. Arpan and Robin L. Nabi, "Exploring Anger in the Hostile Media Process: Effects on News Preferences and Source Evaluation," Journalism \& Mass Communication Quarterly 88, no. 1 (2011): $5-22$.

40. Soza, "Leaders of the Pack."

41. David Broughton, "Report Spotlights Female Fans," Sports Business Daily, October 14, 2013. 
42. Antonio William, Isabell Rhenwrick, Kwame J. A. Agyemang and Alexandria Pantaleoni, "An Exploratory Study of Women Club Members' Experiences with an NFL Brand Extension," Sport, Business and Management: An International Journal 5, no. 2 (2015): 107-120.

43. Anne Cunningham Osborne and Danielle Sarver Coombs, Female Fans of the NFL: Taking their Place in the Stands (New York: Routledge, 2015).

44. James N. Druckman and Cindy D. Kam, "Students as Experimental Participants: A Defense of the 'Narrow Database,"' in Cambridge Handbook of Experimental Political Science, ed. James N. Druckman, Donald P. Green, James H. Kuklinski and Arthur Lupia (New York: Cambridge University Press, 2011), 41-57. 